\author{
Nasar MEER \\ Strathclyde University, UK \\ Tariq MODOOD \\ University of Bristol, UK
}

\title{
Religious pluralism in United States and Britain: its implications for Muslims and nationhood
}

\begin{abstract}
This article provides a historically informed analysis of the contemporary incorporation of Islam and Muslims into an idea of common - national - membership in the United States and Britain. It shows that there is a movement underway for synthesis between religious and national identities by Muslims themselves, and the ways in which this synthesis is occurring within rich and dynamic public spheres in these societies that have historically included and incorporated other religious groups. We argue that while both countries are currently wrestling with the extent to which they can accommodate Muslims in ways that allow them to reconcile their faith and citizenship commitments, Establishment in the UK is no less successful at achieving this than secular republicanism in the US.
\end{abstract}

\section{Keywords}

American Muslims, British Muslims, citizenship, nationhood, religious pluralism

\section{Résumé}

Cet article fournit une analyse historiquement informée de l'incorporation actuelle de l'islam et des musulmans dans une idée d'appartenance commune - nationale - aux États-Unis et en Grande-Bretagne. Nous montrons qu'il existe un mouvement en cours généré par les musulmans eux-mêmes promouvant la synthèse entre les identités religieuses et nationales. Nous analysons les façons dont cette synthèse se produit dans les sphères publiques riches et dynamiques de ces sociétés qui ont historiquement inclus et intégrés d'autres groupes religieux. Enfin, nous soutenons que si les deux pays sont actuellement aux prises avec les limites dans lesquelles ils peuvent accueillir les musulmans d'une manière qui leur permettent de concilier leurs engagements en matière de foi et de citoyenneté, l'établissement au Royaume-Uni ne connaît pas moins le succès atteint par le républicanisme laïque aux États-Unis. 


\section{Mots-clés}

citoyenneté, musulmans américains, musulmans britanniques, nation, pluralisme religieux

\section{Introduction}

In this article we explore how Muslims have been incorporated into conceptions of nationhood in Britain and the United States. Scholarship on national identity has long recognised the close connection between religion and nationhood. The variety of territorially anchored Protestant churches in post-reformation Europe illustrate this relationship, and even where organised religions have not achieved the 'Established' status of Anglican or Lutheran Churches, or been subject to church-state separation, this has not resulted in God-state separation. This observation is partly why Ernest Barker (1948: 14) insisted that 'nations [have] long dreamt for their national unity in some common fund of religious ideas'. Linda Colley's (1992: 362) characterisation of an earlier Britain as 'a protestant Israel', and Geoff Levey's (2009) reminder that despite its wall of separation, the US has always remained 'One Nation Under God' affirm Barker's earlier observation. Going further, in his Chosen People: Anglo-American Myths and Reality, Longley (2002: 10) insists that 'we are never going to reach the bottom of issues of national identity until we delve into the religious dimension [...] Religion is a 
weightier ingredient in these national stories than most modern English people or Americans would expect' (cf Wuthnow, 2006).

This article contributes to these broader debates by focusing on how contemporary appeals to national identities react to Muslim 'differences'. Specifically, we explore the extent to which the British experience is consistent with Casanova's (2009: 140-141) conclusion that:

while in the United States the new immigrant religions have mainly contributed to the further expansion of immigrant religious pluralism, in the case of Europe, immigrant religions present a greater challenge to local patterns of limited religious pluralism, and even more importantly, to recent trends of drastic secularisation.

Our aim is to contribute a historically contextualized analysis of the contemporary incorporation of Islam and Muslims into an idea of common - national - membership in these two countries.

We begin by outlining the particular configuration of religion and nationhood in each context. We then discuss the ways in which Islam and Muslims rest in - and revise - each church-state settlement and prevailing conceptions of nationhood. We conclude by examining the implications for theories of religious pluralisms. Our observation is that there is a movement underway for a synthesis of religious and national identities by Muslims themselves, and that both the US and the UK boast rich public spheres and dynamic civil societies in which such synthesis is possible. While both countries are 
currently wrestling with how to incorporate Muslims, in a manner that reconciles faith and citizenship commitments, and so is not governed by racializing discourse and policy, we demonstrate that the Established UK is no less successful at this than the US.

\section{I-The 'perils of modelling'}

The title of this section is taken from Viet Bader's (2007: 871) preference for the use of 'fairly disaggregated frames' in studying the dynamics of state-church relations, in that 'State-Church relations do not "determine" but "shape" accommodation policies' for more recent religious minorities (Bader, 2007: 880, cf Fetzer and Soper, 2005). We broadly agree with Bader's position, particularly its encouragement of a context-sensitive approach. We do, however, still find it helpful to utilise the idea of contrasting 'models' loosely defined - to explore the incorporation of Muslims into existing social and political configurations of nationhood in the United States and Britain.

It is often stated that the First Amendment of the US Constitution erects a 'Jeffersonian' wall of separation between church and state by mandating that Congress 'shall make no law respecting an establishment of religion, or prohibiting the free exercise thereof'. Upon this relatively slender constitutional stipulation has come to rest a great deal of legal and political architecture that has been elaborated and tested in primary legislation, precedent, and practice. Two particular features of this history are relevant to our discussion. One is that within the historical practice of the idea of absolute separation there have actually been more complex outcomes that go beyond the privatisation of religion per se. Examples include the provision of government resources to religious organizations that deliver social services; some significant tax benefits enjoyed by 
religious organizations; the prominence of religion in civil society, and the relationship between political parties and religious organisations

The main focus of our discussion is on a second implication. Despite its theoretical rejection of 'all political or economic privilege, coercion, or disability based on religious affiliation, belief, or practice, or lack thereof' (Weber, 1998: 685), the US retains and reflects cultural vestiges of Anglo-Saxon Protestantism, which may consign some minority religions to the periphery. This need not be a politically multiculturalist critique, given Tocqueville's (1969: 292) observation that 'in the United States it is not only mores that are controlled by religion, but its sway extends over reason', to the extent that even with the First Amendment 'Christianity reigns without obstacles, by universal consent...although the world of politics seems given over to argument and experiment'.

While it is true that the Protestant core has been a persistent obstacle to incorporating religious groups outside of it, through Tocquevillian processes of 'argument and experimentation' Catholic and Jewish groups have historically sought inclusion. Levey (2009: 9) lists a series of Jewish campaigns opposing Sunday closing laws, and supporting denominational schooling and holidays, which illustrate how 'in the United States the new immigrant religions have mainly contributed to the further expansion of immigrant religious pluralism' (Casanova, 2009: 140-141). In the time between Tocqueville's observation and Casanova's celebration, however, there has been much contestation in the $r$-forging of an American public culture in which 'being a Protestant, a Catholic or Jew are three acceptable ways of expressing American identity, that being religious has become in fact an evidence of adherence to national values' (Wilson, 1966: 89-90). In his Protestant, Catholic, Jew (1955), Herberg frames the study 
of religion in the United States through analysis of how national culture is saturated with religious movements and institutions. This illustrates how nationhood and religion enter a dynamic relationship which produces new touchstones for identification. As Wilson (1966: 90) describes:

In the recent historical development of America instead of religion being the source of such values as patriotism and the sense of national allegiance, as was the case in Europe, the acquisition of American nationality...has come in time to need a further affirmation, and that affirmation has been found in religious affirmation.

Importantly, Wilson argues that for religion to be appropriated in the course, or renewal, of nation building, it would have to minimise religious differences such that 'all faiths might serve the same end, and become more similar to each other in doing so' (Wilson, 1966: 98). Bellah (1967) too understood the American story as one that had taken on the hallmarks of a 'civil religion'; one in which a conception of the 'nation' is imbued with Christian language, rhetoric, and values. This presents an exception to Levey's (2009: 5) view that 'the religion model and the nation-state model have different logics and press in opposite directions', but is consistent with the broader 'paradox' of American religious and ethnic pluralism (e.g., 'hyphenated identities') illustrated in the notion of JudeoChristian American nationhood. The latter category was perhaps facilitated by three factors. The first is that numerically American Jewry - unlike American Catholics never presented a demographic challenge to Protestant predominance. The second, is that 'Judaism in America did not encounter...religiously based anti-Semitism' (Casanova, 2009: 157), for reasons related partly to the third issue that in general American 
Protestantism has tended to maintain a philio-Hebraic attitude' (Casanova, 2009: 157). ${ }^{1}$ The centrality of the Judeo-Christian concept to the wider discourse of American nationhood is powerfully summarised by Connolly (1996: 57):

...'the American people', 'our culture', 'our children', 'the Judeo-Christian tradition', 'family values', or 'common sense'...summons the imagination of a country in which each regular individual is a microcosm of the nation and the nation is the macrocosm of the regular individual. The church, the nuclear family, the elementary school, the media and the university are institutions that must maintain these two primal units of culture as reflections of each other. The endlessly reiterated phrase 'the American people' captures this combination precisely....

So how does this religiously infused, but potentially re-made, relationship between religion and nationhood contrast with models of nationhood in Europe, especially in the light of Casanova's (2009: 140-141) unfavourable contrast of the latter as quoted above?

There are a number of ways in which Britain does not fit Casanova's portrayal. While it is quite true that the established Episcopal Church expresses the continuing Christian identity of England, this is in spite of the consistent challenges to its superior status by other Christian denominations, as in Scotland, where the religious majority is Presbyterian, which led to the creation of a Church of Scotland. Indeed, 'the failure of the established Church to represent sections of the population dates back to the middle of the seventeenth century' (Trigg, 2007: 21), thus in England and Wales, Protestant nonconformists have been vocal. Further, Wilson (1966: 99) maintains that, 'Nonconformity was a challenge to the idea of social consensus implicit in the existence 
of an Established Church which assumed itself to be the religious expression of the nation'.

The cycles of $19^{\text {th }}$ century migration from Ireland to London, Glasgow, and the north of England considerably expanded the Roman Catholic presence in Britain. The turn of the $20^{\text {th }}$ century, meanwhile, witnessed the arrival of destitute Jewish migrants fleeing both pogroms and economic deprivation in Russia. Both groups have been subject to processes of racialization and civil discrimination on the basis of their religious affiliation, but in due course have come to enjoy some of the benefits initially associated with 'Establishment'. This includes allowing the Catholic Church to set up schools alongside the state and then, in the 1944 Education Act, to opt into the state sector and receive similar provisions to those enjoyed by the established Church; a provision which was soon extended to other religious groups, notably Jewish minorities (around half of whom are educated in state funded denominational schools).

What this shows is that Britain is not the case of 'limited pluralism' Casanova understands it to be, insofar as immigrant religions do not necessarily face greater obstacles in British modes of religious pluralism than in the US. Trigg elucidates the question they do encounter (2007: 23): 'if we say that the Church of England is somehow the repository of English identity, might that not suggest that those who are not Anglicans are somehow less than English?'. Trigg's answer is ambiguous, but concedes that the Established church 'can at times represent all Christian voices in the country, and even ensure that other faiths can receive proper, public, recognition'. Trigg points particularly to the House of Lords Select Committee's insistence that 'the constitution of the United Kingdom is rooted in faith - specifically the Christian faith' (quoted in Trigg, 2007: 24). 
We concur with Trigg's recognition of the deep historical role of Britain as an Established country, though one which has also developed a 'moderate secularism' (Modood, 2010a) that is able to accommodate non-Christian faiths without disestablishment by selectively pluralising the church-state link through constitutional reform, public policies and social services delivery. This reflects 'how established or institutionalised patterns, like principles and rights (of religious freedoms, for example) have been and have to be continuously re-interpreted and re-framed, and framing depends on competing discourses of incorporation, on discourse coalitions and power relations, and on crucial events' (Bader, 2007: 880).

Symbolically, this prospect is illustrated in recent years in the moderately controversial statement from Prince Charles (Prince of Wales and heir to the throne) that as the next figurehead of the Established Church he could be the Defender of Faith rather than Defender of The Faith. Much more controversially, Dr Rowan Williams - the former Archbishop of Canterbury - publicly considered what degree of accommodation the law of the land can and should give to minority communities with their own strongly developed legal and moral codes (Modood 2010b). He spoke particularly of Britain's experience with Islamic sharia courts and their capacity to rule on such matters as family disputes and claims. For the purposes of forging a coherent nationhood that is inclusive of more than a majority religion, therefore, both of these moves invite a 'shift in the selfrecognition of a dominant constituency [which] works best if it acknowledges the shifting and historically contingent character of, say, the sensualities, language, faith, and canonical texts that have inspired it the most' (Connolly, 1996: 61). 
Britain has faced its own challenges in addressing social disadvantages tied to cultural differences as experienced by a variety of ethnic and religious minorities. The most substantive response developed cumulatively during the final quarter of the last century and comprised a range of policies and discourses commonly known as 'multiculturalism'. Multiculturalist efforts strive for equality of access and accommodation of aspects of minority difference, while also promoting the social and moral benefits of ethnic minority-related diversity in an inclusive sense of civic belonging (Meer, 2015). Indeed, at a public policy level Britain rejected operationalizing integration as a drive for unity through an uncompromising cultural 'assimilation' over 40 years ago, when then-Labour home secretary Roy Jenkins (1966) defined integration as "not a flattening process of assimilation but equal opportunity accompanied by cultural diversity in an atmosphere of mutual tolerance'. This has been a neither linear nor stable development, however, and has frequently been criticized not only by a variety of camps who - for different reasons - militantly opposed it, but also by those who 'accept[ed] multicultural drift grudgingly as a fact of life, regretting the passing of the good old days when, they believe, Britain was a much more unified, predictable sort of place' (Commission on the Future of Multi-Ethnic Britain, 2000: 14).

\section{II-Configurations of Muslims and the state}

An examination of issues characterizing specifically Muslim integration and accommodation in the US and UK is now appropriate given that many of the historical multi-faith settlements were achieved with non-Muslims in mind, and some have argued that Muslims present a unique challenge to religious pluralism. According to Joppke 
(2009: 108) 'if one considers that explicit Muslim claims did not emerge in earnest before 1989, the year of the Rushdie controversy in Britain... the speed and depth of accommodating Muslims [has] been breathtaking'. Joppke (2009: 111) explains this by claiming that 'in pious Muslims there reverberates the archaic power of religion, which is not merely subjective belief, but objective truth, which cannot leave room for choice'. This quite narrow interpretation ignores how, while 'Muslims are religiously active, they lack the political power that well established churches have historically enjoyed, thereby threatening their capacity to win state recognition for their religious needs' (Soper and Fetzer, 2010: 12). The issues of claims-making and accommodation go to the heart of our discussion, though they vary across the US and UK contexts.

Haddad and Lummis (1987: 3) were among the first to insist that 'The religion of Islam is now an American phenomena'. Whether or not their optimism was premature, their description of the subsequent empirical state of affairs is undeniable. According to Smith (2010: 29) 'America today is home to the most heterogeneous Muslim community at any time or place in the history of the world'. Cainkar (2010: 177) details that: 'By 2005 the number of Muslim Americans had reached an estimated 6-7 million, although the estimate is disputed, the majority of whom lived in medium to large-sized American cities and were born outside the US'. There is some debate on the precision of these figures because the survey of religion in the national Census is prohibited, but the broad proportions are supported by a number of authors (see Ba-Yunus and Kone, 2004), and most estimations suggest Muslims now marginally outnumber Jews (Mazrui, 2004: 118). One striking and often overlooked feature of American Islam is not only that 'Islam is the second-largest expression of Black religion in the United States' (Jackson, 2005: 18), but 
that 'among the great Western democracies, America is unique in that the largest single group of its Muslims consists of indigenous converts'. Indeed, 'whereas prior to 1975 American Islam had been dominated by Black Americans, by early 1980s immigrants had moved into a position of political, economic, and intellectual dominance' (Jackson, 2004: 216). Despite an earlier historical record, for a long time the Muslim presence in the US was synonymous with the modern African-American experience ${ }^{2}$, which perhaps commences with the 1913 founding of Noble Drew Ali's 'Moorish-American Science Temple', before W. D. Fard created the 'Nation of Islam' (NOI) in 1930, and thorough which the conversion of African-Americans, under the subsequent direction of Elijah Muhammad, became common. ${ }^{3}$

As a result of both this historical presence and subsequent migration and postmigration settlement, there are estimated to be over 1200 mosques, 300 Muslim organisations, 200 student groups, 200 Muslim Schools, 100 media groups, and 50 world social services and relief organisations. The most widely known are the largest 'umbrella' groups of The Islamic Society of North America (ISNA), the Muslim American Society (MAS), the American Muslim Council (AMC), the Council of American-Muslim Relations (CAIR), the Muslim Public Affairs Council (MPAC), and the American Muslim Alliance (AMA). Grewal (2014: 128) understands these groups as forming part of the 'dramatic reshuffling of Muslim American religious leadership', which she traces to three developments. The first is the migration and reordering of American Muslims as majority-Sunni; the second is the configuration of professional and managerial classes that make up the American Muslim constituency; and finally the shift in racial dynamics from 'Black Muslims' to 'Muslims' as the Muslim constituency was broadened, 
especially in the public mind. At the same time, some of these organisations seek to follow paths established by earlier groups, often viewing Jewish minorities as a successful example (Mazrui, 2004: 119). Al-Alwani (2004: 7) details institutional progress in a number of key areas which build upon the concessions afforded to other groups. For example:

In 1992, the Pentagon approved the appointment of religious instructors inside the three branches of the U.S. Armed Forces. The first minister, Chaplain Abdul-Rasheed Muhammad, was inaugurated in an official ceremony... The number of mosques and Islamic institutions and schools markedly increased, and 1997 was designated the year of the introduction of Islam and Muslims to the United States.

Equally important is to acknowledge that, unlike the experience of American Jews, Muslim American political activism is inevitably being defined by post- 9/11 domestic and international struggles. This tendency is evident in the Council of American Islamic Relations' (CAIR) (2006) statement that, 'regardless of the cause for a more politically conscious Muslim community, there are more politically active Muslims engaging in proactive discourse and professional activism than there was ten years ago'.

To this end the political scientist and public intellectual Muqtedar Khan (2004) often turns to the American Constitution to ask: 'What is in this constitution that an Islamic state would not like to provide it's people?'. In so doing, the broader project he 
seeks to navigate is that between 'Muslim realists' and 'Muslim idealists' (Muqtedar Khan, 2004: 103-104). The realists, he argues,

are incensed with the United States for having an utter disregard for Muslim lives and Muslim society. The media demonises Islam, everyone gets away with defamation of Muslims... Muslim realists are not impressed with America's democracy or its values of freedom and pluralism. They point to the secret evidence act, used only against Muslims, which violates both these values by not allowing defendants full access to due process...

In contrast,

Muslim idealists have not only transformed American Muslims from a marginal, inward-looking immigrant community to a reasonably wellorganised and well-coordinated interest group... Muslim idealists were quick to grasp the significance of the constitutional guarantee of religious freedom in the United States. (Muqtedar Khan, 2004: 105)

He continues: 'They are not Americans who are Muslims or Muslims who have been born in the United States. They are American Muslims' (107). Khan instead seeks to move beyond either 'outright rejection' or 'blind imitation' of both readings by encouraging American Muslims to develop 'first-hand' accounts of their own. 
Khan's invocation of the constitution was particularly pertinent in the dispute over the proposed building of The Cordoba Centre, an Islamic Center now named the Park 51 Project (widely referred to as the Ground Zero Mosque), two blocks from the site of the World Trade Centre buildings. The wider context for this controversy has been a securitisation of Muslim-state relations and increasing experiences of Islamophobia (Gosh, 2010). 'In the fraught, post September $11^{\text {th }}$ political climate', argues Grewal (2014: 301), 'the triumphal narratives of a Muslim American Dream no longer ring out in Muslim American counter publics as they did in the nineties'.

Whilst Britain too has undoubtedly witnessed some securitization of ethnic relations, it is not quite the case, as one commentator has suggested, that state-Muslim relations amount to being 'tough on mosques, tough on the causes of mosques' (Fekete 2004: 25). Based upon data from the last decennial census (2011), between 2001 and 2011 the Muslim population grew by almost $1.2 \mathrm{~m}$ to $2.7 \mathrm{~m}$, increasing its share of the population from $3 \%$ to around $4.8 \%$ (Jivraj, 2013). This makes Islam the most populous faith in Britain after Christianity (59.3 percent); more numerous than Hinduism (less than 1.5 percent numbering 816,633$)$, Sikhism (0.8 percent equivalent to 423,158), and Judaism (0.5 percent numbering 263,346). Muslims in Britain, as in the US and globally, are pre-dominantly Sunni, within which the two largest sects - the Barelvis and Deobandis - are of South Asian origins. Heterogeneity of ethnic, national and theological cleavages has led Ansari (2004: 3) to insist that:

presumptions of Muslim homogeneity and coherence which claim to override the differences... do not necessarily correspond to social reality. 
A Sylheti from Bangladesh, apart from some tenets of faith, is likely to have little in common with a Mirpuri from Pakistan, let alone a Somali or Bosnian Muslim.

While such readings guard against thinking of Muslims in Britain as a monolithic group, it is equally true that certain concerns transcend Muslim difference - particularly since the (albeit slim) majority of British Muslims have not migrated to Britain but have been born here. Shared concerns are likely to encompass strategies to combat antiMuslim racism, or a desire amongst some Muslim parents to school their children in Islamic traditions, and so on. A national body was created to represent mainstream Muslim opinion and lobby on behalf of Muslims in the corridors of power. With some encouragement from the main national political parties, the Muslim Council of Britain (MCB) was accepted as a consultee by the New Labour government of 1997 till about the middle of the next decade when it looked for new interlocutors. The MCB was very successful in relation to its founding agenda. By 2001, it had achieved its aim of having Muslim issues recognised separately from issues of race and ethnicity, and of being itself accepted by government, media and civil society as the spokesperson for Muslims. Another two achieved aims were the state funding of Muslim schools on the same basis as Christian and Jewish schools, and in getting certain educational and employment policies targeting the severe disadvantages facing Pakistanis and Bangladeshis (who are nearly all Muslims) as opposed to targeting only minority ethnicity generally. Additionally, it played a decisive role in getting Tony Blair to go against ministerial and civil service advice and insert a religion question into the 2001 Census (Sherif , 2011). 
This laid the groundwork for the possible introduction of policies targeting Muslims to match those targeting groups defined by race, ethnicity, or gender. Laws against religious discrimination were introduced in 2003 and strengthened in both 2007 and 2010, making them much stronger than anything available in the rest of the European Union. Incitement to religious hatred, the legislation most closely connected to the protests over The Satanic Verses, was introduced in 2006, though there is no suggestion that it would have caught that novel. Indeed, the protestors' original demand that the blasphemy law be extended to cover Islam has been made inapplicable as the blasphemy law was abolished in 2008 - with very little protest from anybody. Moreover, even as the MCB, because of its views on the government's foreign and security policies, fell out of favour, local and national consultations with Muslim groups have continued to grow and probably now exceed consultations with any Christian body and certainly any minority group. Inevitably, this has caused occasional friction between Christians and Muslims, but overall these developments have taken place not only with the support of the leadership of the Church of England, but largely in a spirit of interfaith respect. This respect is particularly striking when compared to the adversarial stance of some evangelical Christian Islamophobic discourses in the U.S.

One further issue that has come to the fore is the provision of mortgages compliant with Islamic approaches to saving and investing, and the operation of Shar'ia law in civil matters more broadly. For example, the Islamic teaching that riba (usury or interest) is haram (forbidden) is a guiding tenet for some observant Muslims, but is made implausible by systems of financial products which either generate or charge interest. One alternative system which has organically developed in Britain includes an 
arrangement where banks buy property on a customer's behalf, but then sell it back to the customer with an additional charge equivalent to the total amount of interest. For some time, however, this incurred two sets of stamp duty (a tax which is payable to the government on the purchase of a house). In 2003, then-Chancellor of the Exchequer Gordon Brown abolished this double charge, and since then the Council of Mortgage Lenders and $\mathrm{MCB}$ have continued to liaise with various government departments on how to make Islamic home finance products more viable in the UK. ${ }^{4}$

Further, since the 1970s some marital and inheritance disputes have been judged by Muslim arbitration boards if both parties have freely consented to such adjudication, and this has taken place under the broader remit of English civil law. Where the application of Shar'ia has contravened English civil law it has been rejected by the courts, as Pearl and Menski's (1988: 57-58) otherwise critical account of British traditions of positive law has detailed. These kinds of developments illustrate the ways in which 'it is theologically naïve and historically misguided to assume Islam is any more inherently incapable of making peace with liberal democratic values than are Christian and Jewish traditions (Soper and Fetzer, 2010: 13).

It is true that since $9 / 11$, and especially since the London bombings of July 2007 , Muslim communities have become objects of public suspicion and fear, and targets of extensive and often draconian surveillance and security measures, and 175 British Muslims have been convicted on terrorism-related charges (though not as many as the 261 charged and not convicted, Home Office, 2013). Moreover, the media coverage in relation to Muslims and Islam often uses stigmatizing terms including fundamentalist, fanatic, and extremist (Moore et al., 2008), and nearly half of respondents in a survey 
agree that 'there are too many Muslims' in the country (Zick et al., 2011). Nevertheless, these dynamics have also inadvertently empowered some Muslim actors by bringing them into and funding them as civil society participants in certain spheres of governance (O'Toole et al., 2015).

In fact, despite the securitisation of the Muslim communities and openly expressed antipathy, Muslim self-identification as British and trust in public institutions is higher than it is among non-Muslims. Heath and Roberts' (2008) analyses of the UK Government's Citizenship survey found 'no evidence that Muslims or people of Pakistani heritage were in general less attached to Britain than were other religions or ethnic groups. Ethnic minorities show clear evidence of 'dual' rather than 'exclusive' identities' (Heath and Roberts, 2008: 2). These authors point instead to hyphenated identities, in showing that $43 \%$ of Muslims belong 'very strongly' to Britain and $42 \%$ say that they belong 'fairly strongly'. Taken together these figures are higher for Muslim respondents than they are for Christians or those of 'no religion' (Heath and Roberts, 2008: 2). What is especially interesting is that this confident British Muslim identity has developed alongside pan-Muslim solidarities, including the idea of the Muslim 'ummah' or 'community of believers'. The evidence suggests that 'Muslim trans-nationalism should not be treated as a post- or near- $9 / 11$ phenomenon, but rather as a space and set of practices that have evolved over decades' (Mandaville, 2009: 497). This has proved quite consistent with the widely accepted body of findings, recently reiterated by Wind-Cowie and Greogory's (2011: 41) conclusion, that 'overall British Muslims are more likely to be both patriotic and optimistic about Britain than are the white British community'. 


\section{III-Conclusions: The implications for theories of religious pluralisms}

The implications of this analysis are significant for theories of religious pluralisms. It is evident that there is a movement underway for synthesis between religious and national identities by Muslims themselves, and that this synthesis is facilitated by the rich public spheres and dynamic civil societies that have historically incorporated other religious minorities in both the US and UK. Further, the Established UK is no less successful at this than the US. It is true that no effort has been made to disestablish the Church of England, and this has led many to argue that the constitutional status of the Church makes it more difficult for Muslims to achieve the kind of integration into the nation that their co-religionists are achieving in the United States. Kymlicka (2009: 548), for example, has argued that 'American denominationalism... has been successful precisely in relation to ... religious groups composed primarily of recent immigrants, and Muslims in particular', who are more likely than European Muslims 'to express the feeling that their religion and religious freedoms are fully respected, and that they are accepted as citizens'. Similarly, it has been said of the US, in explicit contrast to certain European countries like Britain, that ' $[w]$ ithout the separation of church and state, we believe, the religions imported by past immigration streams could not have achieved parity with Protestant versions of Christianity' (Foner and Alba, 2008: 379). Bhargava (2011) further argues that the 'weak establishment' or 'moderate secularism' of Britain alienates the majority of Muslims.

What problematizes this type of argument is that there is no evidence that Anglican Establishment actually alienates British Muslims. British Muslims include many vociferous political groups and between them they have proffered numerous critiques of socio-economic deprivation, religious discrimantion, incitement to religious 
hatred, various foreign policies, anti-terrorist policies and so on. Yet, there is no record of any criticism by a Muslim group in relation to Establishment. However, many Muslims do complain that Britain is too unreligious and anti-religious, too hedonistic, consumerist, and materialist. The difficulty that Britain has with incorporating Muslims arguably has more to do with what Casanova identifies as the 'recent trends towards drastic secularisation' (Casanova, 2009: 141). Hence, if the US is better at integrating postimmigration religious minorities, this may be due not to non-establishment, but the greater presence and social status of religion and its closeness to the mainstream of society (a point recognized by Casanova, 2009 and by Foner and Alba, 2008). Indeed, while the US may be more of a secular state than Britain, the latter is more of a secular society and has a much more secularist political culture. As such, two quite different social compacts are at work: in the British case the 'deal' is that the religious majority can have state recognition at the highest level, but then it must exercise self-effacement in relation to the democratic process, if not public culture as well (Modood, 2009). In contrast, the 'deal' in the US is that if all churches can agree to allow a certain limited area of public life as 'religiously neutral' and 'beyond religion', the rest of public life is an open field for religion. In the US, all religious groups are free to lead the nation, to seek to make the nation in their own image - as long as it is not through establishment. While both nations differ dramatically in the normative role religion plays in their political cultures, we argue that both can offer meaningful routes for not only political participation, but meaningful incorporation, to their respective Muslim minorities.

\section{Funding}

This research received no specific grant from any funding agency in the public, commercial or not-for-profit sectors. 


\title{
Notes
}

\footnotetext{
${ }^{1}$ This is in contrast to the initial fate of Catholicism which was perceived as a threat because 'it was viewed as a un-American-religion, insofar as Republicanism and Romanism were defined as being incompatible' (Casanova 2009: 157).

${ }^{2}$ There is an important genealogy of a much longer presence of Islam in the Americas. For example, Levtzion and Hopkins (2000: 169) point to evidence of pre-Columbian voyages by Mansa Musa of Mali. Elsewhere Bukhari, Nyang, Ahmad and Esposito (2004: xvii) recount the story of the Arab scholar Al-Idrissi whose works were allegedly carried by Columbus on his voyage.

${ }^{3}$ The NOI departs from orthodox Islamic traditions in two respects. Firstly, and while believing that the Prophet Muhammad was the final prophet, it upholds the view that Elijah Muhammad was a further messenger. Secondly, the NOI emphasises skin colour in a manner that departs from conventional Islamic teaching.

${ }^{4}$ See MCB press release 9 April, 2003.
}

\section{Bibliography}

\author{
Al-Alwani TJ (2004) Toward a Fiqh for Minorities: Some Reflections. In: \\ Bukhari Z, Nyang SS, Ahmad M and Esposito JL (eds) Muslims' Place \\ in the American Public Square. New York: Altamera Press, pp: 3-37.
}

Ansari H (2004) 'The Infidel Within': Muslims in Britain since 1800. London: Hurst.

Ba-Yunus I and Kone K (2004) Muslim Americans: A Demographic Report. In: Bukhari Z, Nyang SS, Ahmad M and Esposito JL (eds) Muslims' Place in the American Public Square. New York: Altamera Press, 299-322.

Bader V (2007) The Governance of Islam in Europe: The Perils of Modelling. Journal of Ethnic and Migration Studies 33(6): 871-886.

Barker E (1948) National Cultures and the Factors in its Construction. London: Methuen \& Co.

Bellah RN (1967) Civil Religion in America. Journal of the American Academy of 
Arts and Sciences 96(1): 1-21.

Bhargava R (2011) Beyond Moderate Secularism. The Immanent Frame. Available at: http://blogs.ssrc.org/tif/2011/09/16/beyond-moderate-secularism/ View 23 June 2015

Bukhari Z, Nyang SS, Ahmad M et al. (2004) Hope, Fears, and Aspirations: Muslims in the American Public Sphere. In: Bukhari Z, Nyang SS, Ahmad M and Esposito JL (eds) Muslims' Place in the American Public Square. New York: Altamera Press, $126-158$

Cainkar L (2010) American Muslims at the dawn of the $21^{\text {st }}$ century. In: Cesari J (ed.) Muslims in the West after 9/11. New York: Routledge.

Cassanova, J (2009) Immigration and new religious pluralism: a European UnionUnited States comparison. In: Levey G and Modood T (eds) Secularism, Religion and Multicultural Citizenship. Cambridge: Cambridge University Press.

Colley L (1992) Britons. New Haven: Yale University Press.

Council of American Islamic Relations (CAIR) (2006) What is the American Muslim Community's Role?

Commission on the Future of Multi-Ethnic Britain (CMEB) (2000) The Future of MultiEthnic Britain. London: Profile Books.

Connolly WE (1996) Pluralism, multiculturalism and the nation-state: rethinking the Connections. Journal of Political Ideologies 1 (1): 53-73.

Fekete L (2004) Anti-Muslim Racism and the European Security State. Race and Class 46(1): 4-29.

Fetzer JS and Soper JC (2005) Muslims and the State in Britain, France and Germany. Cambridge: Cambridge University Press.

Foner N and Alba R (2008) Immigrant religion in the US and western Europe: Bridge or barrier to inclusion?. International Migration Review 42 (2): 360-392.

Grewal Z (2014) Islam is a Foreign Country: American Muslims and the Global Crisis of Autrhority. NYC: New York University Press.

Gosh, B. (2010) 'Islamophobia: Does America Have a Muslim Problem?', Time Magazine, 30 August, 2010: 
http://content.time.com/time/magazine/article/0,9171,2011936,00.html Viewed 23 June 2015

Herberg W (1955) Protestant, Catholic, Jew: An Essay in American Religious Sociology. Garden City, NY: Doubleday.

Haddad Y and Lummis AT (1987) Islamic Values in the United States: A Comparative Study. New York: OUP.

Heath A and Roberts J (2008) British Identity, Its Sources and Possible Implications for Civic Attitudes and Behaviour. Research report for Lord Goldsmith's Citizenship Review.

Home Office (2013) Terrorism arrests - analysis of charging and sentencing outcomes by religion, London. Available at: https://www.gov.uk/government/publications/terrorism-arrests-analysis-ofcharging-and-sentencing-outcomes-by-religion/ (Viewed 23 June 2015)

Jackson S (2005) Islam and the Blackamerican: Looking Toward the Third Resurrection New York: OUP.

Jackson S (2004) Preliminary Reflections on Islam and Black Religion. In: Bukhari Z, Nyang SS, Ahmad M and Esposito JL (eds) Muslims' Place in the American Public Square. New York: Altamera Press, 201-221

Jenkins R (1966) Address given by the Home Secretary to a meeting of Voluntary Liaison Committees. 23 May 1966. London: NCCI.

Jivraj S (2013) Muslims in England and Wales: Evidence from the 2011 Census. In: Alexander C, Redclift V and Hussain A (eds) The New Muslims. London: Runneymede Trust, 16-19.

Joppke C (2009) Veil: Mirror of Identity. Cornwall: Polity.

Khan AM (2004) Living on Borderlines: Islam beyond the Clash and Dialogue of Civilisations. In: Bukhari Z, Nyang SS, Ahmad M and Esposito JL (eds) Muslims' Place in the American Public Square. New York: Altamera Press, 84-113.

Kymlicka W (2009) Review Symposium: Historic settlements and new challenges: Veit Bader, Secularism or Democracy?. Ethnicities 9(December): 546-552. 
Levey G (2009) Secularism and religion in a multicultural age. In: Levey G and Modood T (2009) (eds) Secularism, Religion and Multicultural Citizenship. Cambridge University Press, 216-242.

Levtzion N and Hopkins JEP (2000) (eds) Corpus of Early Arabic Sources for West African History. Princeton: Weiner.

Longley C (2002) Chosen People: Anglo-American Myth and Reality. London: Hodder $\&$ Stoughton.

Mandaville P (2009) Muslim transnational identity and state responses in Europe and the UK after 9/11. Journal of Ethnic and Migration Studies 35(3): 491-506

Mazrui AA (2004) Muslims between the Jewish Example and the Black Experience: American Policy Implications. In: Bukhari Z, Nyang SS, Ahmad M and Esposito JL (eds) Muslims' Place in the American Public Square. New York: Altamera Press, $117-153$

Meer, N. (2015) Citizenship, Identity and the Politics of Multiculturalism. Basingstoke: Palgrave.

Modood T (2009) Introduction: Old Ways of Being Secular. Social Research 76(4): 1169-1172.

Modood T (2010a) Moderate Secularism, Religion as Identity and Respect for Religion. Political Quarterly 81( 1): 4-14.

Modood T (2010b) Multicultural Citizenship and the Shari'a Controversy in Britain. In: Adhar R and Aroney N (eds) Shari'a in the West. Oxford: Oxford University Press, 33-42.

Moore K, Mason P and Lewis J (2008) Images of Islam in the UK: The Representation of British Muslims in the National Print News Media 200-2008. Cardiff:

Cardiff .University,

O’Toole T, Meer N, DeHanas D et al. (2014) Governing through Prevent? Regulation and Contested Practice in State-Muslim Engagement. Sociology, DOI: 0038038514564437

Pearl D, Menski W (1988) Muslim Family Law. London: Sweet and Maxwell. 
Sherif, J., (2011) 'A Census chronicle - reflections on the campaign for a religion question in the 2001 Census for England and Wales', Journal of Beliefs and Values, 32 (1), 1-18.

Smith J (2010) Islam in America. In: Cesari J (ed.) Muslims in the West after 9/11. NewYork: Routledge.

Soper JC and Fetzer JS (2010) The not so naked public sphere: Islam and the State in Western Europe. German Journal for Politics, Economics and Culture of the Middle East 11(2): 6-14.

Tocqueville A (1969) Democracy in America. New Yorker: Harper \& Row.

Trigg R (2007) Religion in Public Life. Oxford: Oxford University Press.

Weber PJ (1988) Separation of church and state: a potent, dynamic idea in political Theory. In: Wuthnow R (ed.) The Encyclopaedia of Politics and Religion. London: Routledge.

Wilson B (1966) Religion in Secular Society. London: C.A. Watts \& Co.

Wind-Cowie M and Greogory T (2011) A Place for Pride. London: DEMOS

Wuthnow R (2006) American Mythos. Princeton: Princeton University Press.

Zick A, Kupper B and Hovermann A (2011) Intolerance, Prejudice and Discrimination: A European Report. Berlin: Friederich Ebert Stiftung.

\section{Author biographies}

Nasar MEER is a Reader in Comparative Social Policy and Citizenship, and Royal Society of Edinburgh Research Fellow (2014-2019) at Strathclyde University. His publications include: Citizenship, Identity \& the Politics of Multiculturalism: The Rise of Muslim Consciousness (2015, Palgrave 2nd Edition); Interculturalism and Multiculturalism: Debating the Dividing Lines (co-edited, 2016 EUP), Racialization and Religion (Edited, 2014 Routledge), Race and Ethnicity (2014, Sage), and European Multiculturalism(s): Religious, Cultural and Ethnic Challenges (co-edited, 2012 EUP). $\mathrm{He}$ is an elected member of the UK Social Policy Association Executive (SPA), and in 2014 he was elected to the Royal Society of Edinburgh's Young Academy of Scotland.

His website is www.nasarmeer.com

Address: Faculty of Humanities and Social Sciences, Lord Hope Building, 141 St James Road, Glasgow G4 0LT, University of Strathclyde, UK 
Email: nasar.meer@strath.ac.uk

Tariq MODOOD is Professor of Sociology, Politics and Public Policy, the founding Director of the University of Bristol's Research Centre for the Study of Ethnicity and Citizenship, and the co-founding editor of Ethnicities. He was awarded a MBE for services to social sciences and ethnic relations in 2001 and was elected a member of the Academy of Social Sciences in 2004. He served on the Commission on the Future of Multi-Ethnic Britain, the National Equality Panel and currently is on the Commission on Religion and Belief in British Public Life. His latest books include Multiculturalism: A Civic Idea (2 ${ }^{\text {nd }}$ ed; 2013); and as co-editor Religion in a Liberal State (2013) and Multiculturalism Rethought (2015). His website is www.tariqmodood.com

Address: Centre for the Study of Ethnicity and Citizenship, SPAIS, University of Bristol, 11 Priory Road, Bristol BS8 1TU, UK

Email:t.modood@bristol.ac.uk 